\title{
Academic Burnout and Some Related Factors in Medical Students
}

\author{
Zahra Mostafavian ${ }^{1}$, Arezou Farajpour ${ }^{2,3}$, Shadan Nessari Ashkezari ${ }^{4}$, Zahra Abbasi Shaye ${ }^{5 *}$ \\ 'Department of Community Medicine, Mashhad Branch, Islamic Azad University, Mashhad, Iran \\ ${ }^{2}$ School of Medical Education, Shahid Beheshti University of Medical Sciences, Tehran, Iran \\ ${ }^{3}$ Educational Development Center, Mashhad Branch, Islamic Azad University, Mashhad, Iran \\ ${ }^{4}$ Department of Community Medicine, Mashhad Branch, Islamic Azad University, Mashhad, Iran \\ ${ }^{5}$ Clinical Research and Development Unit, Akbar Hospital, Mashhad University of Medical Sciences, Mashhad, Iran; \\ drabbasi_94@yahoo.com
}

\begin{abstract}
Background and Aim: Academic burnout is the feeling of inadequacy and mental fatigue induced by chronic stress in students lacking the necessary resources to carry out their duties and tasks assigned to them. This study aimed to determine academic burnout and some related factors in medical students of Islamic Azad University of Mashhad in 2015-2016. Materials and Methods: In this cross-sectional study, 181 medical students in degrees of basic sciences, traineeship, and internship were selected by convenience sampling. The data collection instrument was the Persian version of the Maslach Burnout Inventory Student Survey and a checklist of demographic variables. The collected data were analyzed using SPSSv. 18 software, descriptive and analytical tests, such as t-test and ANOVA. Results: The mean total score of academic burnout was $34.69 \pm 14.69$. It was concluded that $23.2 \%$ of the subjects had a high level of burnout and $51.4 \%$ a moderate level. No significant relationship was found between age, marital status, having the second job, and the educational level without any of the dimensions and the total score of the burnout questionnaire $(\mathrm{P}>0.05)$. The mean of academic dissatisfaction was higher in men than in women $(\mathrm{p}=0.01)$. With regard to the place of residence, the mean score of inefficiency in the student home was significantly higher than that of the dormitory $(p=0.04)$. Conclusion: The results of the study showed that a significant percentage of students suffer from academic burnout. In this study, female gender played a protective role in the dimension of academic dissatisfaction and living in a dormitory in the area of inefficiency.
\end{abstract}

Keywords: Academic Burnout, Islamic Azad University, Maslach Burnout Inventory Student Survey, Medical Students

\section{Introduction}

Burnout refers to a state of mental and emotional fatigue resulted from chronic stress syndrome, high pressure from role and time limits, and a lack of necessary resources to carry out the responsibilities ${ }^{1,2}$. The concept of burnout was proposed by Fredenberger for the first time in the early 1970s. In the beginning, burnout was paid attention in professional interaction among individuals with an emphasis on interpersonal relationships among demanders and suppliers ${ }^{3}$. Nowadays, burnout variable has expanded to other situations including educational situations which is called academic burnout ${ }^{4,5}$. Burnout is the main inevitable consequence of stress ${ }^{6}$. The nature of medicine major causes it to be called as the most stressful professions. In addition to experiencing the stress of theoretical courses, the students of this field also undergo other types of stress such as the stress of presence in hospital which is one of the most stressful workplaces due to dealing with life and death $^{7}$. Academic burnout is prevalent among medical stu- dents. Dyrbye et al (2008) reported the prevalence of academic burnout among $50 \%$ of American medicine students ${ }^{8}$. In their study, Masry et al (2013) figured out that $76.8 \%$ of medical students of $6^{\text {th }}$ year suffered from severe burnout and $71.7 \%$ of them understood a high level of stress?.

There are different reasons for considering academic burnout as a significant field of research, including the effect of burnout on academic performance, the students' commitment to accomplish the educational tasks of the faculty, and their interest to continue their studies and participate in science after graduation ${ }^{10}$. In their study, Mikaeili et al (2013) concluded that there is a negative significant relationship between educational and academic performance, which means with more academic burnout among students, they will have a weaker performance ${ }^{11}$. Academic burnout is an important problem that the educational system is suffering from, which has both negative effects at the time of education and other long-term negative effects after graduation. Relevant studies have shown that students who experience depression during their educa-

*Author for correspondence 
tion will master their occupational responsibilities less in the future, make less use of the research studies conducted in their occupational field, and are more willing toward turnover after being employed ${ }^{11}$. Due to the importance of academic burnout among medical students and since few studies have focused on academic burnout among medical students in Iran, the present study was carried out in order to examine academic burnout and some related factors in medical students of Islamic Azad University of Mashhad.

\section{Methods}

The present descriptive-analytical cross-sectional study was carried out on 181 medical students of Islamic Azad University of Mashhad who were studying at three levels of basic sciences, traineeship, and internship in 2015-16. The students were selected by a convenience sampling method. The sample size

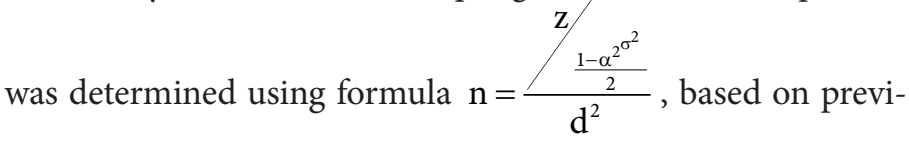
ous studies ${ }^{13}$ in which the average burnout score was $40.7 \pm 10.29$, at confidence interval of $95 \%$, and variation level of 1.5 .

Inclusion criteria were studying in the academic year 201516 and willing to participate in the study, and the exclusion criteria were being an exchange student, not responding to all questions of the questionnaire, and unwilling to continue participating in the study.

The data collection instrument was Maslach Burnout Inventory Student Survey (MBI-SS) and a demographic information checklist to collect data on age, gender, educational level, place of residence, marital status, and job. This inventory assesses three dimensions of academic burnout, academic disinterest (pessimism), and educational inefficacy. It has 15 items that are scored based on a 7-point Likert scale (the scores ranging from 0 to 6). The academic burnout dimension has 5 items (Lesson materials are tiring), the academic disinterest dimen- sion 4 items (I feel I'm not interested in lesson materials), and the educational inefficacy 6 items (I feel I can't deal with my lesson problems). Questions 1, 4, 10, and 13 are related to the subscale of academic burnout, questions 2, 5, 11, and 14 to pessimism (disinterest), and questions $3,6,8,9,12$, and 15 to educational inefficacy. However, since educational efficiency (positive sentences) are used in this subscale, the questions of this part are scored inversely ${ }^{14}$. This inventory is normalized in Iran ${ }^{15}$. The present study was approved and encoded R.IAU. MSHD.REC. 1396.58 by the Ethics Committee. Oral consent was obtained from all participants, and they were assured about the confidentiality of their information. The collected data were fed into SPSS v18. Kolmogorov-Smirnov test was run to check the normality of the quantitative variables. Due to normal distribution, comparing the quantitative variables of the two groups was carried out using t-test for two independent groups and ANOVA for over two groups. The level of statistical significance was set at $\mathrm{p}<0.05$.

\section{Results}

One hundred eighty-one medical students of basic sciences, traineeship, and internship participated in the present study. The results showed that participants' average age was 23.8(2.1) years, and $19.3 \%$ of the students were studying basic sciences, $51.4 \%$ traineeship, and $29.3 \%$ internship. It was also observed that $76.2 \%$ of the participants were female and $23.8 \%$ male, $22.7 \%$ were married and $77.3 \%$ were single, $93.9 \%$ did not have a job and $6.1 \%$ worked, and $76.2 \%$ lived with their families, $16 \%$ in dormitories, and $7.7 \%$ at student houses. Following other studies ${ }^{16,17}$, percentiles 25 and 75 were used to divide academic burnout score in terms of its severity into low, average, and high groups. The mean and standard deviation of the students' score on academic burnout (total score) and its three subscales and frequency distribution of burnout severity are presented in Table 1.

Table 1. The mean and standard deviation of academic burnout and its dimensions, frequency distribution of severity of academic burnout

\begin{tabular}{|c|c|c|c|c|}
\hline Academic burnout score & Minimum & Maximum & Mean & Standard deviation \\
\hline Emotional exhaustion & 0 & 30 & 13.70 & 6.13 \\
\hline Academic disinterest & 0 & 24 & 7.41 & 4.92 \\
\hline Inefficiency & 3 & 29 & 14.12 & 5.92 \\
\hline Total burnout & 5 & 83 & 34.60 & 14.69 \\
\hline Severity of academic burnout & \multicolumn{2}{|c|}{25.4} \\
\hline Low & \multicolumn{2}{|c|}{51.4} \\
\hline Average & \multicolumn{2}{|c|}{23.2} \\
\hline High & \multicolumn{2}{|c|}{100.0} \\
\hline Total & \multicolumn{2}{|c|}{} \\
\hline
\end{tabular}


In order to compare burnout scores based on the participants' age, they were divided into two groups: under 24 and equal or over 24 . The group under 24 consisted of 88 students (48.6\%). Comparing the average score of academic burnout score and its total score based on the participants' age did not show a significant statistical difference among the scores ( $p>0.05$ ). Comparing the average score of academic burnout score based on the participants' gender indicated that mean emotional exhaustion, academic inefficiency, and total academic burnout score did not have a significant statistical difference $(p>0.05)$. However, based on gender, the mean score of academic disinterest had a significant difference. In general, academic disinterest was higher among men than women $(p=0.01)$. Based on the participants' marital status, the mean emotional exhaustion, academic inefficiency, academic disinterest, and academic burnout did not have a significant statistical difference $(p>0.05)$. Mean scores of emotional exhaustion, academic inefficiency, and academic disinterest, and total score of academic burnout did not have a significant statistical difference in different educational stages ( $p>0.05$ ). Moreover, based on the students' place of residence, the mean scores of emotional exhaustion, academic disinterest, and academic burnout did not have a significant statistical difference ( $p>0.05)$. However, based on their place of residence, the mean score of academic inefficacy had a significant difference $(p<0.05)$. After Tukey test was run in order to pair compare the means, there was a significant difference the mean academic inefficacy score of the students living in student houses (15.31 $\pm 5.85)$ and dormitories $(14 \pm 5.8)(\mathrm{p}=0.04)$.

\section{Discussion}

The present study was carried out in order to examine academic burnout and related factors in medical students of Islamic Azad University of Mashhad in the academic year of 201516. The results showed that $51.4 \%$ of the students had average academic burnout and 23\% had severe academic burnout. The results of the study conducted by Sharififard et al on 264 medical and paramedical students in Qom University of Medical Science in 2013 showed that $24.1 \%$ and $46.6 \%$ of the students respectively had high and average academic burnout ${ }^{16}$. The results of a study carried out by Kamalpour in order to examine the relationship between resilience and academic burnout among nursing students in Kerman showed that $50.9 \%$ and $21.7 \%$ of the students had average and high levels of academic burnout, respectively ${ }^{17}$.

Nikodijevic et al (2012) studied 376 management and IT students in Serbia and concluded that $46.3 \%$ of the students at risk of developing academic burnout and $20.7 \%$ had a high level of academic burnout ${ }^{18}$. In the study conducted by Dyrbye (2008), 2154 US medical students were studied, and the results showed that about $50 \%$ of them had academic burnout and $10 \%$ experienced suicide thoughts during their medical studies ${ }^{8}$. Kuittinen (2011) carried out a study entitled, "The effect of study related burnout on student perceptions" which included 3031 students of 9 universities of Finland. The results of that study showed that $45 \%$ of the students were at risk of academic burnout ${ }^{19}$. The results of the mentioned studies are in agreement with those of the present one with regard to frequency of academic burnout. The results of all these studies put emphasis on developing methods to prevent and deal with academic burnout among all students especially medical students who are directly related with the society's both physical and mental health. Regarding the relation between gender and academic burnout, the results of the present study showed that among different dimensions of academic burnout, only academic disinterest had a significant relationship with gender, such that the mean score of academic disinterest among men and women was respectively 9.09 and 6.9. The results of the study carried out by Uludag on tourism students in a university in Northern Cyprus indicated that male students had higher levels of burnout than females ${ }^{20}$. With regard to the effect of gender on academic burnout, the results of the present study are in line with those of the studies carried out by Yan et al (2004) in Taiwan ${ }^{21}$ and Costa et al $(1992)^{22}$. On the contrary, the results of the study carried out by Duran et al showed that women had higher levels of burnout than $\mathrm{men}^{13}$. In the studies carried out by Sharififard et $\mathrm{al}^{24}$, Charkhabi et $\mathrm{al}^{16}$, Akansel et $\mathrm{al}^{24}$, and Kamalpour et $\mathrm{al}^{17}$ did not report a significant between gender and dimensions of academic burnout. Such an inconsistency can be attributed to different statistical populations in cultural terms and also different proportions of men to women in different studies; therefore, it seems necessary to carry out further studies. With regard to the relationship between marital status and academic burnout, the results of the present study showed that there was no significant relationship between marital status and academic burnout and its dimensions, which is in agreement with the results of the investigations conducted by Kamalpour et $\mathrm{al}^{17}$, Sharififard et $\mathrm{al}^{16}$, and Akansel et $\mathrm{al}^{24}$. The results of the present study proved no significant relationship between age and academic burnout and its dimensions. This finding is in line with those reported by Sharififard et $\mathrm{al}^{16}$, Costa et $\mathrm{al}^{25}$, Kamalpour et $\mathrm{al}^{17}$, and Duran et $\mathrm{al}^{13}$. It seems that lack of a significant relationship between age and academic burnout is related to the participants' small range of age. Regarding the relation between job and academic burnout and its dimensions, the results of the present study proved no significant relationship, which is in line with the results of the study carried out by Sharififard et al (2014) but not with those carried out by Dyrbye et $\mathrm{al}^{8}$ and Akansel et $\mathrm{al}^{24}$. This difference can be attributed to the fact that a small percentage of the participants had a job or that the participants of different studies had different jobs. In the present study, there was no significant relationship between educational degrees and academic burnout, which is in line with the results reported by Sharififard et $\mathrm{al}^{16}$. This difference can be attributed to the fact that different educational levels were focused on in the 
two studies. With regard to the relationship between place of residence and academic burnout and its dimensions, the results of the present study also indicated that there was a significant relationship between the subscale of academic inefficiency and place of residence, such that students who were living in student houses had a significantly higher academic inefficiency scores than those living in dormitories. This finding was not in line with those of the study conducted by Sharififard et $\mathrm{al}^{16}$. This difference seems to be the result of different statistical populations; Sharififard et al studied nursing and paramedical students, while the present study focused on medical students. In should be stated that medical students have a higher level of responsible taking and stress control compared to other individuals.

Among the limitations of the present study was selecting the participants by a convenience sampling method. Future studies are recommended to select their participants randomly.

\section{Conclusion}

According to the results of the present study, a remarkable percentage of the students suffered from average and severe levels of academic burnout. It is recommended that further studies focusing should be conducted in order to identify factors affecting academic burnout among medical students and adopt appropriate strategies to reduce it which can create grounds for social and behavioral disorders among medical graduates in the future.

\section{Acknowledgements}

The author would like to thank all dear students who helped with conduction of the present study.

\section{References}

1. Iacovides A, Fountoulakis KN, Kaprinis S, Kaprinis G. The Relationship Between job Stress, Burnout and Clinical Depression. Journal of Affective Disorders. 2003; 75(3): 209-21. https://doi.org/10.1016/S0165-0327(02)00101-5

2. Torker S, Shirom A, Shapira I, Berliner S. The Association Between Burnout, Depression, Anxiety, and Inflammation Biomarkers: C-Reactive Protein and Fibrinogen in Men and Wome. Journal of Occupational Health Psychology. 2005; 10(4):344-62. https://doi.org/10.1037/1076-8998.10.4.344 PMid:16248685.

3. Maslach C, Schaufeli WB, Leiter MP. Job Burnout. JOB BURNOUT. 2001; p. 397-422.

4. Salmela-Aro K, Savolainen H, Holopainen L. Depressive Symptoms and School Burnout During Adolescence: 3 Evidence from Two Cross-lagged Longitudinal Studies. Journal of Youth and Adolescence. 2008; 38(10):1316-27. https://doi.org/10.1007/s10964-008-9334-3 PMid:19779808.
5. Schaufeli WB, Martinez IM, Marques A Pinto, Salanova M, Arnold B Bakker. Burnout and Engagement in University Students. Journal of Cross-Cultural Psychology. 2002; 33(5):464-81. https://doi.org/10.1177/0022022102033005003

6. Watson R, Deary I, Thompson D, Li G. A study of stress and burnout in nursing students in Hong Kong: A questionnaire survey. International Journal of Nursing Studies. 2008; 45(10):1534-42. https://doi.org/10.1016/j.ijnurstu.2007.11.003 PMid:18241870.

7. Abazari F, Abbaszade A, Arab M. An Evaluation of the Sources of Stress in Nursing Students. Strides in Development of Medical Education. 2012; 1(23-31).

8. Dyrbye LN1, Thomas MR, Massie FS, Power DV, Eacker A, Harper W, Durning S, Moutier C, Szydlo DW, Novotny PJ, Sloan JA, Shanafelt TD. Burnout and suicidal ideation among U.S. medical students. Annals of Internal Medicine. 2008 Sep 2; 149(5):334-41. PMid:18765703.

9. El-Masry R, Ghreiz SM, Helal RM, Audeh AM, Shams T. Perceived Stress and Burnout among Medical Students during the Clinical Period of Their Education. Ibnosina Journal of Medicine and Biomedical Sciences. 2013; 5(4):179-88. https://doi.org/10.4103/1947-489X.210543

10. Neumann Y, Reichel A. Determinants and Consequences of Students' Burnout in Universities. The Journal of Higher Education. 1990; 61(1):20-31. https://doi.org/10.2307/1982032

11. Mikaeili N, Afrooz G, Gholiezadeh L. The Relationship of SelfConcept and Academic Burnout with Academic Performance of Girl Students. Journal of School Psychology. 2013; 1(4):124-30.

12. Rudman A, Gustavsson P. Burnout During Nursing Education Predicts lower Occupational Preparedness and Future Clinical Performance: A longitudinal Study. International Journal of Nursing Studies. 2012; 49(8):988-1001. https://doi.org/10.1016/j.ijnurstu.2012.03.010 PMid:22542085.

13. Duran A, Extremera N, Rey L, Fernandez-Berrocal P, Manuel Montalban F. Predicting Academic Burnout and Engagement in Educational Settings: Assessing the Incremental Validity of Perceived Emotional Intelligence beyond Perceived Stress and General Self-efficacy. Psicothema. 2006; 18(1):118-26.

14. Schaufeli WB, Martinez IM, Marques-Pinto A, et al. Burnout and engagement in university students: A cross national study. Journal of Cross-Cultural Psychology. 2002; 33(5): 464-81. https://doi.org/10.1177/0022022102033005003

15. Rostami Z, Abedi MR, Schaufeli WB, Ahmadi SA, Sadeghi AH. The psychometric characteristics of Maslach burnout inventory student survey: A study among students of Isfahan University. Zahedan Journal of Research in Medical Sciences. 2014; 16(9): 55-8.

16. Sharififard F, Nourozi K, Hosseini MA, Asayesh H, Nourozi M. Related Factors with Academic Burnout in Nursing and Paramedics Students of Qom University of Medical Sciences in 2014. Journal of Nursing Education. 2014; 3(9):56-68.

17. Kamalpour S, Azizzadeh-Forouzi M, Tirgary B. A Study of the Relationship between Resilience and Academic Burnout in Nursing Students. Strides in Development of Medical Education. 2017; 13(5):476-87. 
18. Nikodijevic A, Andjelkovic-Labrovic J, Djokovic A. Academic Burnout Among Students at Faculty of Organizational Sciences. Management: Journal for Theory and Practice Management. 2012; 64(6):47-54. https://doi.org/10.7595/management. fon.2012.0019

19. Kuittinen $M$, Merilainen $M$. The effect of study related burnout on student perceptions. Journal of International Education in Business. 2011; 4(1):42-62. https://doi.org/10.1108/18363261111170586

20. Uludag $\mathrm{O}$, Yaratan $\mathrm{H}$. The effect of burnout on engagement: an empirical study on tourism students. Journal of Hospitality, Leisure, Sport and Tourism Education. 2010; 9(1):13-23. https://doi.org/10.3794/johlste.91.243

21. Yang H-J. Factors Affecting Student Burnout and Academic Achievement in Multiple Enrollment Programs in Taiwan's Technical-Vocational Colleges. International
Journal of Educational Development. 2004; 24(3):283-301. https://doi.org/10.1016/j.ijedudev.2003.12.001

22. Costa P, McCrae JAR. Normal Personality Assessment in Clinical Practice: The NEO Personality Inventory. Psychological Assessment. 1992; 4(1):5-13. https://doi.org/10.1037/10403590.4.1.20 https://doi.org/10.1037/1040-3590.4.1.5

23. Charkhabi M, Azizi Abarghuei M, Hayati D. The association of academic burnout with self-efficacy and quality of learning experience among Iranian students. Springer Plus. 2013; 2:677. https://doi.org/10.1186/2193-1801-2-677 PMid:24386623 PMCid:PMC3872283.

24. Akansel N, Tunkc GC, Ozdemir A, Tugutlu Z. Assessment of Burnout Levels among Working Undergraduate Nursing Students in Turkey: Being a Full Time Employee and Student. International Journal Of Caring Sciences. 2012; 5(3):328-34. 